\title{
Of gossips, eavesdroppers, and peeping toms
}

\author{
Huw W S Francis Community physician, London
}

\section{Author's abstract}

\begin{abstract}
British accounts of medical ethics concentrate on confidentiality to the exclusion of wider questions of privacy. This paper argues for consideration of privacy within medical ethics, and illustrates through the television series 'Hospital', what may go awry when this wider concept is forgotten.
\end{abstract}

Breaches of privacy and confidentiality are assumed to be remote and unusual occurrences. In fact, they are common. We appreciate this when we discover ourselves to be the subjects of gossip, or the objects of eavesdropping and prying. Only had we been born deaf-mute or remained solitary for the whole of our lives could we have avoided being either victims or perpetrators. Both gossip and eavesdropping may be benign or malignant. Benign gossip is easy, unconstrained talk or writing, especially about persons or social incidents; it is the stuff of social gatherings. All of us, however, have been distressed by the malicious gossip and the persistent eavesdropper. Fortunately, to experience the voyeur is rare; but the peeping tom is never benign.

Modern technology does not change the nature of breaches of privacy; it simply increases the efficiency of the wrong. By 'increasing the efficiency of the wrong' I mean that it aids the penetration of privacy (surveillance techniques); it disseminates the results of the breach more widely (the media); and it deepens the impact on the individual (the collating by computer of personal records). Technology does not present different problems, but the old in new forms. Faced with the demands of technological advance, many act as if situation ethics should apply, as if they presupposed that '. . . our moral reasoning and practice should be based on a readiness to violate some moral requirement in the face of wholly unique situations . . .' ( 1 ). Technology, however, adds no benison of grace to actions which are otherwise disreputable.

In Western society over the last 300 years or so there

\section{Key words}

Privacy; confidentiality; medical ethics; human rights; doctor-patient relationship; media and medicine; consent. has been an increasing wish to learn how people tick - it is well illustrated in biographies. Those of a religious cast were inquisitive about the way in which the subject faced death. Izaak Walton in his life of John Donne ends his long account of the deathbed:

'Thus variable, thus vertuous was the Life; thus excellent thus exemplary was the Death of this memorable man.' (2)

Fortitude or fear were touchstones both for the interpretation of a life and for the exhortation of others (3). The genre was exploited especially by the earnest Evangelicals of the I9th century (4). Emotional and sexual relationships have replaced death as the paradigms by which the person and the life are understood. Aubrey's notorious tale of Sir Walter Raleigh seducing one of the Queen's maids of honour concludes: '. . She proved with child and I doubt not but our Hero took care of them both . . ' (5). Raleigh is shown as a 'gallant' in the worst sense and a 'gentleman' in the best. These tendencies have been reinforced both by the belief that the events of childhood are powerful determinants of the course of the subsequent life and by the industry with which modern biographers have pursued their meticulous researches (6). In science, as well as the arts, privacy may be breached. John Ziman argues that science is not a lonely struggle with taciturn Nature by the individual, but a public, corporate activity, depending on publication of results and their public criticism, to reach a public consensus: 'science is public knowledge' (7). Insofar as clinical medicine is scientific, it is itself a form of public knowledge. At the other end of the spectrum from the austerities of science, is the ubiquity of pornography. ' . . We live our lives among pornographic images. . . . we absorb such replicas as effortlessly as we swallow our daily bread ... (8). This strong drive to intrude into and to expose what was once hidden makes the trespass of the media within the personal but the froth of a deeper fermentation within modern society. Are we in medicine also less sensitive than we should be to the issues raised by the concept of privacy?

Classical medical ethics present a very exacting standard in this field. The Hippocratic Oath says:

'. . . And whatsoever 1 shall see or hear in the course of my profession, as well as outside my profession in my intercourse with men, if it be 
what should not be published abroad, I shall never divulge, holding such things to be holy secrets.' (9).

W H S Jones, the editor of the first volume of the Loeb Classical Library Hippocrates, draws particular attention to the phrase 'as well as outside my profession in my intercourse with men':

'This remarkable addition is worthy of a passing notice. The physician must not gossip, no matter how or where the subject matter for gossip may have been acquired; whether it be in practice or in private life.' (9).

It requires a total respect for the privacy, not only of patients, but of all. The Oath here reflects the distinction Hannah Arendt discerned in ancient Greece between the public and the private realms. The private or the household sphere was the place where men were driven by their wants and needs in the maintenance and perpetuation of life. 'Natural community in the household therefore was born of necessity, and necessity ruled over all activities performed in it'. The public realm, or that of the polis, was that of freedom; but mastering the necessities of life in the household was a precondition of freedom in the polis (I0). Illness subjected men to necessity and therefore was a private matter.

Florence Nightingale expressed sentiments similar to the Oath in Notes on Nursing, at the end of her chapter on the observation of the patient:

$\because$. . every nurse should be one who is to be depended upon, in other words, capable of being a "confidential" nurse . . . she must be no gossip; no vain talker; she should never answer questions about her sick except to those who have a right to ask them; she must, I need not say, be strictly sober and honest; but more than this, she must be a religious and devoted woman; she must have a respect for her own calling . . .' (I I).

Implicit is the feeling that to reveal what has been learnt in private may be damaging to the patient and the family. Breaches of trust of this kind may be what the moral theologians call detraction, which Häring defines as '. . . any unjustified assertion that infringes the good name of another, even though it is not formally untrue' (12). Aquinas speaks of detraction as '. . . depreciating another's reputation . . . by exposing secrets ...'(13). The issue is the protection of a person's honour and good name by not revealing what may be discreditable or embarrassing (14). An associated fault is undue inquisitiveness: '. . . prying into the doings of others leads to detraction.' (I5). There is always the temptation of schadenfreude when a person of high reputation slips, but the truth of an allegation about another is no excuse for its publication. The standards of behaviour assumed by these writers is high indeed, and consistent with the modern concept of privacy.

\section{Privacy}

Privacy is difficult to define. This can be exaggerated; though we may not be able to put it precisely into words, we are all aware of what a private situation is, and of the kinds of actions which invade and destroy it. Westin (I6) has distinguished four related states covered by the concept: solitude, intimacy, anonymity and reserve.

In solitude a person is free from observation and on his, or her, own. It may be sought for private thought, to complete a piece of writing or for simple relaxation. It must be differentiated from isolation, which is enforced; an isolated person may seek unsuccessfully the company of his fellows. Intimacy is desired by more than one person, usually pairs, to achieve satisfactory personal relationships; others are excluded, and physical distractions may not be allowed into the physical setting. Apart from the obvious - lovers and families others seek out such privacy: collaborators completing a joint project, or businessmen in delicate negotiation. In anonymity, while it is related to solitude, the stress is on the avoidance of identification in a public setting. The person wishes not to reveal who and what he is. Public figures, or ordinary people with public roles like policemen, when off duty wish especially for anonymity. Reserve is the state which enables an individual not to reveal aspects of his innermost self to others.

Ingham (17) has argued that privacy fulfils foure important psychological needs. The first is personal autonomy. This may be served by the possession of cherished objects or by the retention to ourselves alone of special bits of information or secret thoughts, wishes or fantasies. Privacy also gives a place for emotional release. So, for example, the desire of relatives after a funeral to be left alone with their grief is respected. Goffman (18) has drawn attention to the phenomena of 'on-stage' and 'off-stage' behaviour in workers with exacting public roles; thus waiters who are controlled, courteous and cultured with customers in the restaurant may 'regress' to ribaldry and dialect in the kitchen. The third function is self-evaluation, particularly after some major upheaval or crisis in one's life. The fourth function is to allow limited and protected communication and is therefore an important aspect of liberty.

Without privacy the closest of human relationships love, friendship and trust - could not develop (19). In such relationships there must be mutual self-revelation in conditions where each will respect the confidences and the sides of personality shown only when the person is, metaphorically, déshabilée, 'off duty' or 'backstage'. In Aristotle's words: 'friendship requires time and familiarity; as the proverb says, men cannot know each other till they have "eaten salt together" ... '(20). Time, familiarity and 'eating salt' need privacy. If privacy is essential to the best and deepest of our relationships it is bound up with our idea of ourselves as persons, and with our humanity (19). It strongly implies Kant's 'practical imperative': ' . . . always treat humanity, whether in your own person or in the person 
of any other, never simply as a means, but always at the same time as an end.' (2I).

The importance of the concept of privacy in medicine need not be overstressed. Solitude is clearly related to rest and quiet as a necessity in the recovery from illness. Intimacy in Westin's definition is the required setting of the doctor-patient relationship; the circumstances in which trust can grow and the patient can reveal facts and emotions otherwise kept secret. Anonymity is related to confidentiality, that is to say data should not be used in such a way that the subject may be identified. But since some regard illness as demeaning to themselves, they might not wish to be recognised when attending a physician's consulting room or a hospital out-patient clinic. Anonymity is much wider than the protection of verbal information. Reserve extends these ideas. The interaction between patient and doctor, requires the patient to lower his reserve, and this he will not do unless the doctor offers him 'limited and protected communication'. Even then the patient may not reveal all. He may entrust to the doctor sufficient confidence for the treatment of a serious illness; but he may hold to himself his fear and distress. Reserve must be exercised also by the doctor to protect the secrets of his patients.

It is difficult to maintain privacy when our health care is embedded in a system of public institutions. To enter a general practitioner's surgery or a hospital is to forego some privacy. Serious illness nursed in a Nightingale ward gets only limited protection: curtains and screens may hide the patient from sight, but much will be heard. Moreover, the whole apparatus of the welfare state depends on the individuals who need to benefit from its provisions freely making available intimate facts about themselves and their families. The distinction which Hannah Arendt noted in ancient Greece between the private and public realm has been blurred. The sphere where men are driven by necessity - birth, illness, indigence and death - have been incorporated into the concerns of the wider society (22). This is not to say that collective provision for health and social well-being is wrong, but simply that the problem of preserving individual privacy is greatly increased (23).

The concept of privacy is crucial to realising our ideals about the doctor-patient relationship. Charles Fried has argued that the professional relationship between doctor and patient (and between lawyer and client) whilst in many ways cooler, is akin to friendship (24) and therefore raises issues of loyalty from one to the other. Privacy imposes a duty which is wider than that of the customary sharp focus onto confidentiality, and cannot be divorced from the doctor's whole duty to his patient as a person (25).

THE RIGHT TO PRIVACY

The modern right to privacy was first proposed in a most influential paper by Samuel Warren and Louis Brandeis in the Harvard Law Review for 1890 . The purpose of such a right was: 'to protect those persons with whose affairs the community has no legitimate concern, from being dragged into an undesirable and undesired publicity and to protect all persons, whatsoever their position or station from having matters, which they may properly prefer to keep private, made public against their will.' (26).

This 'right to be left alone' is now widely regarded as a fundamental or human right. Two major international codes on rights are subscribed to by the UK: The Universal Declaration of Human Rights of the United Nations adopted in 1948, and the European Convention on Human Rights promulgated by the Council of Europe in 1950. Article 12 of the Universal Declaration says:

'No one shall be subjected to arbitrary interference with his privacy, family, home or correspondence, nor to attacks on his honour or reputation. Everyone has the right to protection of the law against such interference or attack.'(27).

The related provision of the European Convention is Article 8:

I. Everyone has the right to respect for his private and family life, his home and his correspondence.

2. There shall be no interference by a public authority with the exercise of this right except such as is in accordance with the law and is necessary in a democratic society in the interests of national security, public safety or the economic well-being of the country, for the prevention of disorder or crime, for the protection of health or morals, or for the protection of the rights and freedoms of others. (28).

Jacques Velu, Professor of Law at the University of Brussels, identified five major aspects of the right to privacy under the European Convention:

I) Protection of an individual's physical and mental inviolability and his moral and intellectual freedom.

2) Protection against attacks on an individual's honour and reputation.

3) Protection of an individual's name, identity or likeness against unauthorised use.

4) Protection of individuals against being spied on, watched or harassed.

5) Protection against disclosure of information covered by the duty of professional secrecy (29).

Professor Velu's exposition of the European Convention right to privacy includes the major points argued so far in this paper, namely: a fundamental respect for the person; redress for detraction; the need for anonymity; the protection of solitude and intimacy, and the prohibition of breaches of reserve and confidentiality. Many of those aspects of privacy which are important in medicine are therefore justiciable in Europe (30).

BREACHES OF PRIVACY: AN EXAMPLE

In the autumn of 1977 , and again in the summer of 
I978, BBC2 transmitted eight programmes, Hospital, based on the then Bolton Area Health Authority, which are likely to remain the most detailed televised day-to-day examination of the National Health Service (NHS) in the provinces. Hospital is one of the distinguished group of $\mathrm{BBC}$ documentaries using techniques which are variously called ciné vérité, 'observational filming', actualité, or 'fly-on-the-wall', and which includes such programmes as: Sailor, on the former aircraft-carrier, Ark Royal; two about public schools, Westminster and Radley; Strangeways, filmed in the notorious Manchester Prison; and at the time of writing, Police, about the Thames Valley force. More intimate situations may be recorded than with conventional methods and, as one of the makers of Police said:

'You have to accept that you're in an emotionally sensitive position. . . when the stuff of your films is not fiction but other people's lives. But no matter how uncomfortable a situation gets or how much you'd like to leave, you have to steel yourself to stay. You have to steel yourself to be "intrusive", if that's the word . . ' (3I)

The Bolton programmes, like their companion documentaries, were a success, and were much praised. Efforts were made to ensure that the material televised was acceptable, each programme being viewed before transmission by panels locally and in London. Two related features make Hospital unique: first, the publications of the area management team (32-35) permit an analysis of the degree of ethical understanding underlying their enthusiastic participation; and second, from their papers it may be inferred, though they do not say so, that ciné vérité might be consistent with the requirements of medical ethics. The Bolton oeuvre is therefore of considerable interest, though here, where it is being used as a source of illustration only, a full critique is not attempted.

Excellence did not prevent some episodes in each of the BBC documentaries from causing dismay. Hospital was not an exception, and several aspects were disquieting. In particular, the degree of personal identification of the people televised, while the norm in cine vérité documentaries, does not occur in other medical programmes. Usually producers go to much trouble to ensure that patients remain anonymous, or that only sufficient identification is given as is needed for a lucid exposition of the facts. In Hospital the institutions and the geographical location were known, faces were seen and the personal names were not suppressed. The nature of certain incidents gave grounds for greater concern:

An adolescent girl, under I6, was seen being 'washed out' after a suicide attempt. Her face was clearly seen.

The death of, or failure to resuscitate, a young boy after a drowning accident.
A middle-aged man being treated after being beaten up and rolled in pig manure.

Elderly patients in a psychiatric ward whose faces were seen.

An elderly, confused woman was shown being cleaned of her own excreta. At one point in the programme she was seen naked, albeit a back view. Her name became known from a brief interview with her husband.

One case must be looked at more fully. A nursing auxiliary, who was fully identified, had been absent on 225 days between 1974 and 1977; all but 30 of the absences were covered by sick-notes. She had problems at home with her children and her unemployed husband (36). The Radio Times carried the following note, which accurately anticipated the design and content of the programme:

\section{'Two Nurses}

Sister Bleakley works in the ophthalmic ward caring for patients with eye ailments. She is a conscientious nurse and her rewards are correspondingly great. She can rejoice with the old lady who can look out over the town at all the familiar landmarks now that her sight has been restored. And she can share the joy of a young girlo whose severe squint has been corrected by surgery.

While Sister Bleakley plies her skills, another nurse faces a dismissal hearing. With her union officer in attendance she must answer charges of absenteeism. The process closely resembles a trial. After the prosecution, the defence and witnesses have been heard, three adjudicators retire to consider their verdict. All this was recorded behind closed doors as it happened.' (37).

It is worth noting here both the words used, which are associated with the criminal process, trial, charge, etc a wholly unjustified implication - and the pejorative comparison. This is, of course, an extreme example of the televising and the printing of material that is deeply detractive; but each of these six episodes is a breach of one or more of Velu's five principles. Each is either an intrusion into a very personal matter (a death, incontinence or nakedness); the broadcasting of information which should be kept confidential (a suicide attempt); or the televising and printing of material prejudicial to reputation (the circumstances of a dismissal). Some of the explanations the area management team gave for their participation, or justifications in the face of criticism, were:

Of the death of the child, while they cite an antagonistic comment, they quote with approval a view that 'an honest and balanced presentation of the work of a hospital (which is where most Britons die anyway) could not have been given without portraying death'; in other words, a defence by 
frequency. Intimate behaviour, however, is highly prevalent in the community. To argue from frequency to publication is to suggest that no private action is sacrosanct from exposure.

The Bolton area health authority had not received a single formal complaint from any patient or member of staff (35). This is an important measure of administrative success; but 'getting away with it' is not usually regarded as an ethical category.

The Secretary of State is helped by an informed public opinion in his bids for resources. True, but does effective publicity about the NHS require breaches of patients' privacy?

The subjects had given their consent. This will be examined later.

In the light of the undoubted importance of the series and the gravity and extent of the violation of privacy, these comments are surprisingly superficial. The main ethical point made by the Bolton team relates to confidentiality:

'Medical ethics prescribe that a doctor will treat confidentially the information he has learned about a patient in pursuance of his clinical responsibility towards that patient and will not disclose such information without the patient's consent; and his employing authority ... has a parallel duty to ensure that medical records and other confidential information are kept securely and are not released unjustifiably.' (33).

The position of the Bolton team is therefore paradoxical. On the one hand they hold a conventionally high view of the nature of confidentiality; on the other, they were associated with serious intrusions into what was private and personal. In this they seem to me not to be uniquely blameworthy, but merely to reflect a current problem of medical ethics.

\section{The contradictions of confidentiality}

The leading statement on confidentiality in the British Medical Association's handbook says:

'A doctor must preserve secrecy on all he knows.

There are five exceptions to this principle:

I) The patient gives consent.

2) When it is undesirable on medical grounds to seek a patient's consent but is in the patient's own interest that confidentiality should be broken.

3) The doctor's overriding duty to society.

4) For the purposes of medical research, when approved by a local clinical research ethical committee, or in the case of the National Cancer Registry, by the Chairman of the BMA's Central Ethical Committee or his nominee.
5) When the information is required by due legal process.' (38).

The matter was put similarly by a resolution of the Central Committee for Community Medicine.

'. . . the confidentiality of medical records is sacrosanct, and that there is a continuing role for doctors trained in the fields of preventive and educational medicine which can only benefit all individuals in the population if important information is shared freely, but with full precautions to maintain confidentiality, between doctors practising curative and preventive medicine.' (39).

Confidentiality is a most important issue and nothing said subsequently should be taken as seeming to impugn this; however, from these statements three points arise. First, both statements are logically incoherent: in each confidentiality is made sacrosanct; yet, by each, breaches are permitted. Both place the weight of the words on disclosure: the first has 96 words, of which only nine deal with confidentiality, but 87 with the exceptions. Of 54 words in the second, 21 concern secrecy and 33 discovery. They are, therefore, not so much statements on confidentiality, as of the conditions in which secrets may be made known, the reverse of their intention. Second, most of the conditions for breaking confidentiality - duty to society, research, law, prevention and education - are all points wheré the interests of the community, the welfare state, or scientific research impinge on the life of the ordinary citizen. In them, collective or bureaucratic requirements are invoked to serve needs presumed to be larger than the individual. Whilst the ideal of keeping secrets is as old as medicine itself, our contemporary concept of confidentiality is defined in terms which are a response to our increasingly bureaucratic and impersonal society. Third, both statements treat confidentiality as 'given', as a dogmatic rule whose philosophical provenance requires no exposition; in this they do not differ from other enunciations of the principle. The result is to reduce confidentiality to a technical requirement, to a punctilio which, while scrupulously observed, is not well understood.

Recently I have heard both a hospital casualty department and the reception area of a health centre described as 'designed for maximum confidentiality', when clearly the architects had in mind the protection from prying of more than private information. Similarly, in the Bolton series, confidentiality was thought to comprehend the whole duty towards staff and patients in respect of intrusions into the personal. Too much weight tends to be placed on the idea of confidentiality; it has replaced in contemporary discussion of medical ethics, the wider and more fundamental concept of privacy. Confidentiality is, as has been argued already, a diminished principle in itself. The outcome is that the application of the principle of confidentiality, to situations in which it is too narrow or inappro- 
priate, may be reductionist. Far from protecting our patients, it may, as in Bolton, expose people to intolerable disclosures. Our understanding of confidentiality is, therefore, paradoxical.

Confidentiality shares with privacy an important feature which is usually overlooked. Let us suppose that a family doctor sees a lady with arthritis. He may, at the end of the consultation, consider that as well as medical treatment, the patient needs social support. He will, with the patient's consent, discuss her illness with the social worker.The doctor and the social worker have a similar ethic, they share a loyalty to the patient, they have the same aim - the recovery or support of the patient or client, and they will discuss the case from time to time. The breach of confidence is constrained by known and acknowledged commitments of the professional people involved with the patient; this kind of breach I call convergent. The family doctor has a second reason for breaching confidence. $\mathrm{He}$ is co-operating with a survey of the causes of arthritis. With his patient's agreement, the family doctor introduces her to the research physician who interviews and examines her. The research physician, while he shares the same ethic as the family doctor, does not share the same loyalty; his loyalty is to the success of the research project, or to the greater good of mankind, neither necessarily unethical. Nor is his aim the recovery of this patient, but the benefit of future patients as yet unknown. His relationship with the patient, while ethical, is but a simulacrum of the therapeutic one. The breach of confidence is not contained within a known group of continuing professional commitments; this kind I call divergent.

The patient's motives are important too. In accepting the need for a breach of confidence to the social worker, the patient was acting in her legitimate selfinterest, but in co-operating with the research project, she was acting out of altruism (40). Where the law requires a breach of confidence, there must be an element of coercion, but even there altruism cannot be ruled out entirely. Some drivers, suffering from illnesses which affect their safety at the wheel, may admit their disabilities and surrender their licences voluntarily, out of consideration for others. The Central Committee for Community Medicine places a special emphasis on the desirability of divergent breach of confidence (39). Indeed, without it, the administration of the service and the pursuit of preventive medicine would hardly be possible. Because of the need for altruism, it is important not to assume that breaches of confidence can be demanded as a routine. Which leads us on to the question of consent (4I).

\section{Categories of consent}

Both in the right to privacy under the European Convention and in the statements on confidentiality, the consent of the subject releases the professional concerned from the obligation of secrecy. The problem of consent is, as Professor H L A Hart put it, due to our greater knowledge of:

'. . . a great range of factors which diminish the significance to be attached to an apparently free choice or to consent. Choice may be made or consent given without adequate reflection or appreciation of the consequences; or in pursuit of merely transitory desires; or in various predicaments when the judgment is likely to be clouded; or under inner psychological compulsion; or under pressure from others of a kind too subtle to be susceptible of proof in a court of law . . .'(42).

It is notorious that medical institutions are in their nature coercive, even when the staff are sensitive and concerned. A philosophy don writing of a short stay in a fine teaching hospital said:

'Am I glad to be home? Am I! Everyone who looked after me was wonderfully careful and considerate. Yet the institution was hell ... No amount of care can compensate for the loss of identity and autonomy.' (43).

There is a more fundamental issue: is consent given by a patient to release medical information about himself of the same kind as, say, that given for a surgeon to repair a hernia? Paul Ramsey argues that:

'... The principle of an informed consent is a statement of the fidelity between the man who performs medical procedures and the man on whom they are performed . . . The principle of an informed consent is the cardinal canon of loyalty joining men together in medical practice and investigation. In this requirement, faithfulness among men - the faithfulness that is normative for all the covenants or moral bonds of life - gains specification for the primary relations peculiar to medical practice.' (Ramsey's italics). (44).

The advice given to photographers who undertake 'glamour work' is to use what significantly is called a 'model release form'. The form signed by the model allows the photographer to use the photographs as he wishes, whether retouched or not, to use the photographs to represent an imaginary person and to attribute any wording, provided the woman's actual name is not used (45). That is, the photographer is allowed to use the likeness of his model for what would otherwise be an attack on her good name, and in a way that is detractive. The photographer is released from fidelity between him and his sitter; there is no canon of loyalty here.

There is a clear analogy between consent and the analysis of breaches of confidence above. Ramsey's idea of fidelity involved in clinical consent strongly suggests that clinical consent is convergent, a binding together of the parties. Consent to breach of privacy is 
divergent because the doctor who passes on information, by the same act also loses control of it. He can give no fiduciary bond that untoward consequences will not follow. This applies even to the example above of the social worker; the doctor cannot be absolutely certain what she might divulge within her own profession or organisation. Each consent to a breach of privacy or confidentiality is a release from part of the loyalty between a doctor and his patient. The doctor in seeking consent to disclose is closer to the 'glamour' photographer than to the surgeon offering treatment. To regard consent to treatment and consent to breach of privacy as if they were continuous each with the other, is to be guilty of a category mistake.

In consent for medical treatment, the physician or surgeon does not take this as an unfettered licence to carry out the treatment irrespective of the patient's ultimate well-being. If a patient has given consent for, say, a repair of a hernia, but arrives at the hospital with a chest infection, the surgeon will delay the operation until the patient's chest is better. Similarly, a consent to breach privacy should not be taken at face value. The doctor is under an obligation to consider the wider interests of the patient dependent on his professional judgment. Is there a possibility that publicity may damage his client? In the example of the dismissal of the nursing auxiliary in Bolton, the printed and televised material was deeply detractive. Moral theologians would probably regard that publicity for her as morally undesirable, even though she gave consent. There is a long-held principle that it is impermissible for anyone to multilate himself physically, or to do anything voluntarily which will damage his health (46). It is but a small extension to regard consenting voluntarily to the publicising of seriously detractive material about oneself as morally reprehensible. There is an element of ethical peculation in accepting without the most careful thought, and long discussion with the person involved, a consent to serious self-detraction (47).

\section{Sanctions}

In English law there is little or no redress against breaches of privacy or confidentiality. The truth of the statement is itself an absolute defence in an English court against defamation, however discreditable it might be to the person against whom it is directed. There is, however, a certain amount of case law. The Duchess of Argyll wished to publish a book, which was going to be serialised in a newspaper, which related to intimate matters relating to her recently dissolved marriage with the Duke of Argyll. The Duke took out an injunction against the Duchess to prevent the publication of this material. During the course of the judgment the trial judge said:

'An injunction may be granted to restrain the publication of information not only by a person who was a party to the confidence, but also by other persons into whose possession it has improperly come.' (48).

The very influential paper by Warren and Brandeis (26) was based on the analysis of a small number of English cases in the 19th century. Ironically, while the law in other countries has progressed, English common law on this point has remained relatively static. The Argyll case may be the beginning of a change perhaps reflected in the House of Lords' ruling against Granada Television, upholding the confidentiality of a British Steel Corporation memorandum (49). In addition the law of trespass and of nuisance may occasionally offer some remedy but in any event recourse to the courts and appropriate redress are both difficult.

There are four other possible means of action, apart from recourse to the courts, none of them very strong. I) There are the Press Council and the new Broadcasting Complaints Commission. The effect outside the magic circles of the media is probably small. At least a complainant has some satisfaction if complaints are upheld.

2) An aggrieved person can complain against the National Health Service to the Parliamentary Commissioner, the Ombudsman. Of course, the broadcasting authorities do not fall under the Ombudsman's purview, but to the extent that officers or employees of the NHS were responsible for breaches of privacy or confidentiality, then it is likely the commissioner would give some consideration to them.

3) Employees of the NHS would certainly be liable to disciplinary action within the service if they were responsible for breaches of confidentiality. Serious misdemeanours might bring professionals, at least, under the purview of their registering bodies.

4) The European Convention on Human Rights is backed by the Court and Commission on Human Rights in Strasbourg. Subject to the continuing pleasure of Her Majesty's Government, individual citizens of the United Kingdom may take individual complaints against government departments and agencies to Strasbourg. Several have proceeded on health matters, particularly on aspects of detention for psychiatric illness. The position of the $\mathrm{BBC}$, as an official but independent body, is undecided under the European Convention. But certainly proceedings against NHS authorities could be taken by individuals who were aggrieved in matters of privacy and confidentiality, and had gained no satisfaction from other means of redress (50).

While these powers are either weak or difficult to use, they certainly cannot be ignored by health authorities, their officers or their employees, or by the health professions as a whole.

\section{The importance of privacy}

In discussing a ciné vérité documentary on health services as if it might be consistent with medical ethics, the Bolton authors made a serious challenge to the 
concept of privacy. The practitioners of ciné vérité have, at times, 'to steel' themselves 'to be intrusive' (3I), that is, to ignore the ordinary, civilised conventions which protect what is rightly personal. Within ethical discourse, the Bolton papers are, therefore, a reductio ad absurdum and cannot be seriously entertained.

I have been careful to point out that I do not regard the Bolton team as uniquely blameworthy, but as merely reflecting, even if by excess, some current problems of ethical understanding. The contemporary zeitgeist favours exposure of the private and personal. As was seen earlier, attempts to breach privacy may be made as readily by the virtuous as the venal, by the saint as carelessly as the sinner. The dominant ethical principle is confidentiality which covers only a part of the relevant field; it deals with some, but not all, of the concerns which Westin (16) dealt with under anonymity, but hardly touches the issues he raised under solitude, intimacy and reserve. There is also the failure to distinguish between what I have called here convergent and divergent breaches of privacy. The attempts which are being made by new law and codes of practice to protect individuals from breaches of confidentiality in computer systems or research are to be welcomed, because they particularly aim at the divergent. The nature of consent is crucial. In relation to breaches of privacy it is always divergent: the patient is either coerced or has to exercise some degree of altruism to give it; in neither case should a consent given in good faith be abused.

A peculiarity of the British situation is, however, that the provision for the protection of privacy by law or administration is weak, difficult to obtain or remote. This is compounded by the major British handbooks on medical ethics $(38,51,52)$ neglecting the subject. None gives an account of privacy as distinct from confidentiality. Human rights are mentioned by one (5I), but the right to privacy is an absentee. The concept of privacy needs to be revived for two major reasons:

I) It relates medical ethics to modern formulations of human rights. The growing bureaucracy of the state and of large-scale industry and commerce tend to invade personal and family matters more and more. Individuals require protection against the intrusive interests of the collective whether it is constituted as state, corporation, community or group. As Ronald Dworkin put it:

'. . if rights make sense at all, then the invasion of a relatively important right must be a very serious matter. It means treating a man as less than a man, or as less worthy than other men. The institution of rights rests on the conviction that this is a grave injustice, and that it is worth paying the incremental cost in social policy or efficiency that is necessary to prevent it . . ' (53)
Arguments from the common good are frequently used to justify infringing privacy to increase the efficiency of health services, to facilitate research or to aid publicity. It is precisely because it is necessary and wise to yield to these claims in many instances, but not every one, that the protection afforded by a fundamental right is required. The right to privacy under the European Convention is not widely known. Appreciation is increasing of the importance of the European Commission on Human Rights and the European Court of Human Rights in matters relating to mental health services. Unless awareness grows of the hazards in which breaches of privacy may place people in the NHS, then references to Strasbourg on these grounds also may follow. Even if that possibility did not exist, the obligation in the Hippocratic Oath, to hold as holy secrets '... whatsoever I shall see or hear...' requires not a narrow confidentiality, but a wider privacy.

2) Consideration of privacy leads directly to major issues of principle. Privacy is integral to the doctorpatient relationship. Without it, the trust the doctor requires to elucidate the problems of his patient would not be given. In Charles Fried's moving analogy, at its best it is akin to friendship (24). Equally, privacy relates to the dignity of human persons. Public detraction may remove those last shreds of a healing selfrespect. The psychiatrically ill and the mentally handicapped, to create public regard for whom much effort has been expended, can so easily be misrepresented by ill-considered publicity. We must face squarely, to borrow Elizabeth Maclaren's words '. . . our own power to make or unmake one another as persons of dignity' (54). Aquinas divides the virtue of prudence into three parts: good counsel, good judgment according to rules or laws, and good judgment in exceptional cases (55). The exceptional should be judged, he says, 'by certain principles higher than ordinary rules' (56). The advances of modern technology and the greed of the media for the newsworthy present doctors and health service administrators with decisions which are novel in their particulars, but not in principle. A grasp of the concept of privacy is a sound basis for dealing with the unanticipated with discretion.

This paper is therefore a plea that ethical discourse in British medicine should be enlarged from confidentiality to privacy. It is to ask for very little, since to the ordinary, sensitive man and woman there is something unseemly in putting on public display a dying boy, a girl after a suicide attempt, or a naked, incontinent old lady. What is required to protect human dignity is simple: a lively appreciation of the Golden Rule, (57) a little ordinary kindness and empathy. Despite our innate curiosity, our propensity to pry, there is in all of us a natural modesty, a need to withdraw, a wish for privacy. Medicine must be careful that its practices and ethics correspond to the intuitions of ordinary people, intuitions reflected in the disapproving nuances of those common epithets: gossips, eavesdroppers and peeping toms. 


\section{Acknowledgements}

This paper is based on a much earlier version which was given at a meeting in Cheltenham in May 1979 of the South West region of the Faculty of Community Medicine. I am indebted to a number of friends and colleagues for discussing several points with me and for their helpful comments. Gill Welsman, Angela Hulbert and Linda Fairbairn have patiently prepared the various drafts. The views expressed in the paper are personal, and are not necessarily those of any organisation with which I am associated.

\section{References and notes}

(I) Ramsey P. The patient as person. New Haven: Yale University Press, 1970: 4.

(2) Walton I. (I670) The lives of John Donne, Sir Henry Wotton, Richard Hooker, George Herbert and Robert Sanderson. London:Oxford University Press, Reprint I973: 82. World Classics Edition.

(3) One modern interpretation of Donne's death is the reverse of Walton's. It is based on his having been born Catholic and dying Protestant: 'So far as we know, he died an apostate and made no sign' - no sign, that is, of contrition. Rope H E G, quoted by Carey J.Fohn Donne: life, art and mind. London: Faber and Faber, 1981: 26 and 284 .

(4) Cockshut A O J. Truth to life. London: Collins, 1974: I6-79.

(5) Dick O L. ed. Aubrey's brief lives. Harmondsworth: Penguin Books, 1972: 408.

(6) It is ironic, in view of Freud's influence on our knowledge of childhood events in the genesis of adult personality, that his most recent biographer deplores his 'propensity to destroy documents'. Freud wrote to his future wife in 1885 , after an orgy of destruction, ‘. . . I could not have matured or died without worrying who would get hold of those old papers . . . As for biographers, let them worry ...' Clarke R W. Freud: the man and the cause. London: Jonathan Cape and Weidenfeld and Nicholson, 1980: 63 .

(7) Ziman J. Public knowledge. Cambridge: Cambridge University Press, 1968: 8-10.

(8) Vincent S. In tears amid the alien porn The Sunday Times 1981 Sept 13: 34.

(9) Jones W H S. ed. Hippocrates Vol I. London: Heinemann, 1923: 301. Loeb Classical Library.

(Io) Arendt H. The human condition. Chicago: University of Chicago Press, 1968: 30-31.

(II) Nightingale F. (1859) Notes on nursing. Glasgow: Blackie, reprint 1974: 70-7I.

(12) Häring B. Free and faithful in Christ Vol 2. Slough: St Paul Publications, 1979: 91.

(13) St Thomas Aquinas Summa theologiae 2a2ae 73, I. London: Eyre and Spottiswoode, I975: 173 . Vol 38 Blackfriars Edition, Lefébure $M$. translator.

(14) There is a problem of nomenclature in relation to the class of moral faults of which detraction is a member. I have followed Bernard Häring - See reference (12) who uses calumny for allegations which are untruthful and detraction for those which may be truthful. Aquinas, whilst he recognised the distinction Häring draws, wrote of contumelia for public allegations and detractione for secret ones.
(15) St Thomas Aquinas. Summa Theologiae 2a2ae I67, 2. London: Eyre and Spottiswoode, 1972: 209. Vol 44 Blackfriars Edition, Gilby $T$. translator.

(I6) Westin A F. Privacy and freedom. Quoted by Ingham R. Privacy and psychology. In Young J B. ed. Privacy. Chichester: John Wiley, 1978: 39-40.

(17) See reference (I6) Ingham R. 44-46.

(I8) Goffman E. The presentation of the self in everyday life. Harmondsworth: Penguin Books, 1969: 109-140.

(19) Fried C. An anatomy of values. Cambridge, Mass: Harvard University Press, 1970: 140-144.

(20) Ross D. translator. The Nicomachean ethics of Aristotle, $1156^{b}$, 25. London: Oxford University Press, 1954: 196-197. World Classics Edition.

(21) Paton H J. The moral law. London: Hutchinson, I948: 91 .

(22) See reference (10) 45.

(23) It would be wrong to leave the impression that the welfare aspect of the state's activity is uniquely intrusive. The returns on which income tax is based, stemming from William Pitt's Act of 1799 , are almost 150 years older than the welfare state and the inquisitorial features affect more people more frequently. See Monroe H H. Intolerable inquisition?. London: Stevens, I98I: 4-II.

(24) Fried C. Right and wrong. Cambridge, Mass: Harvard University Press, 1978: 179-183.

(25) My paper has been influenced more than I can easily acknowledge, since my indebtedness is general rather than specific, by I E Thompson's essay, The nature of confidentiality, fournal of medical ethics $1979 ; 5: 57-64$. I believe, as will be obvious from the text, that Thomp? son is incorrect, however, to treat privacy as part of confidentiality, and not the reverse.

(26) Warren S D, Brandeis L. The right to privacy. Harvard law review 1890; 4: 193 .

(27) Brownlie I. Basic documents on human rights. Oxford: Clarendon Press, 1971: 109.

(28) See reference (27) p 343.

(29) Velu J. The European Convention on Human Rights and the right to respect for private life, the home and communications. In Robertson A H. ed. Privacy and human rights. Manchester: Manchester University Press, 1973: 12-95.

(30) This paper does not deal with the case law which has developed in the USA some of which has affected matters as diverse as contraception (Wing W R. The law and the public health. St. Louis: C V Mosby, 1976: 55-69) and the withdrawal of life support in the case of Karen Quinlan (Ramsey P. Ethics at the edges of life. New Haven: Yale University Press, 1978: 268-299).

(31) Stewart C producer (with Graef R) of BBC series Police. Quoted by Burn G. Focus on the force. Radio Times I982 Jan 2-8: 76.

(32) Elwood W J, Beveridge M D, Hunter T R, Sutherland R B, Ryder T, Woodcock C. The Bolton TV hospital series: (I) How did it happen?. Hospital and health services review 1978; 74: 43.

(33) Elwood W J, Beveridge M D, Hunter T R, Sutherland R B, Ryder T, Woodcock C. The Bolton TV hospital series: (2) Were we right to say 'Yes' to the BBC?. Hospital and health services review 1978; 74: 43.

(34) Elwood W J. Letter. British medical journal I978; Feb 25: 504.

(35) Elwood W J. The NHS and the media. Community medicine 1979; I: 97. 
(36) The examples are taken from my own notes, made while viewing the second screening of the series in the summer of 1978 .

(37) Radio Times 1978 Aug 28: 31.

(38) British Medical Association. The handbook of medical ethics London: British Medical Association, 1981: 12.

(39) British medical journal I981; 282: 1816.

(40) I use the word altruism as defined by Thomas Nagel: '. . I I do not mean abject self-sacrifice, but merely a willingness to act in consideration of the interests of other persons, without the need of ulterior motives.' The possibility of altruism Oxford: Clarendon Press, 1970: 79.

(4I) My argument which distinguishes convergent and divergent breaches is, I appreciate, oversimplified. Most breaches of privacy have both elements. I do not think that this invalidates the argument.

(42) Hart H L A. Law, liberty and morality. London: Oxford University Press, 1963: 33 .

(43) Belsey A. Don's diary. Times Higher Educational Supplement 1978 June 2.

(44) See reference (I) 5 .

(45) Practical photography i 978 Dec: 5I-55.

(46) Donagan A. The theory of morality. Chicago: University of Chicago Press, 1977: 76-81.

(47) The Bolton workers make much of the fact that the BBC employed a nurse to obtain consents. In their view this was an ethical advance. They seem, however, to have mistaken a new procedure for a matter of principle. Few of the participants seem to have seen the programmes before they were screened, and it is doubtul that the publicity material was discussed with anyone. There was also a marked discrepancy between the agreement between the $\mathrm{BBC}$ and the authority, and the consent form signed by the participants. The consent procedures in Bolton fell far short of the medical requirement of fully informed consent. The Bolton workers also discuss the problem of consent from, or on behalf of, incompetents, which I do not deal with in this paper.

(48) Quoted by Kidd C J F. Freedom from unwanted publicity. In: Bridge J W, Lasok D, Plender R O, Parrott D L, eds. Fundamental rights. London: Sweet and Maxwell, I973: 52. Case reference: Argyll v Argyll [1967] Ch 302.

(49) British Steel Corporation v Granada Television Ltd [I980] 3 WLR 774.

(50) Robertson A H. Human rights in Europe. Manchester: Manchester University Press, 1977.

(5I) Thomson W A R. A dictionary of medical ethics and practice. Bristol: John Wright, 1977.

(52) Duncan A S, Dunstan G R, Welbourn R B. Dictionary of medical ethics. London: Darton, Longman and Todd, I98I. Revised edition.

(53) Dworkin R. Taking rights seriously. London: Duckworth, 1977: 199.

(54) Maclaren E A. Dignity. Fournal of medical ethics 1977; 3: 40-4I.

(55) St Thomas Aquinas. Summa Theologiae razae 57, 6. London: Eyre and Spottiswood, I969: 56-6r. Vol 23 Blackfriars Edition, Hughes W D. translator.

(56) St Thomas Aquinas. Summa Theologiae 2a2ae 5I, 4. London: Eyre and Spottiswood, 1974: 105. Vol 36 Blackfriars Edition, Gilby T. translator.

(57) '... Whatever you wish that men would do to you, do so to them ...'Matt 7:12, The Bible, revised standard version. 